\title{
Pengaruh Penggunaan Limbah Sayuran Dalam Ransum Terhadap Performa Produksi Itik Petelur
}

\author{
E. Saelan ${ }^{1 \mathrm{a}}$ dan A. S. Nurdin ${ }^{1}$ \\ ${ }^{I}$ Fakultas Pertanian, Program Studi Peternakan, Universitas Khairun \\ aemail: emysaelan@gmail.com
}

\begin{abstract}
Abstrak
Penelitian mengenai pengaruh penggunaan limbah sayuran dalam ransum terhadap performa produksi itik petelur telah dilaksanakan di kandang percobaan Produksi Ternak Unggas Fakultas Pertanian Prodi Peternakan Universitas Khairun, Provinsi Maluku Utara. Percobaan menggunakan itik petelur umur 46 minggu sebanyak 64 ekor. Lama penelitian 8 minggu. Metode penelitian menggunakan Rancangan Acak Lengkap (RAL) dengan 4 perlakuan dan 4 ulangan yaitu R0 (100\% Ransum kontrol); R1 (5\% limbah sayuran $+95 \%$ ransum kontrol); R2 (10\% limbah sayuran $+90 \%$ ransum kontrol); R2 (15\% limbah sayuran $+85 \%$ ransum kontrol) dan guna melihat pola kecenderungan masing-masing perlakuan dilakukan uji polinomial ortogonal. Hasil penelitian (1) Produksi telur ratarata yaitu R0 (63,04\%); R1 (65,37\%); R2 (69,79\%); dan R3 (70,57\%) berbeda nyata lebih tinggi dari pada ransum kontrol; (2) Konsumsi ransum yaitu R0 (154,36 gr); R1 (153,66 gr); R2 (151,48 gr) dan R3 $(150,66$ gr) berbeda nyata $(\mathrm{P}<0,05)$ lebih tinggi dari pada ransum kontrol; (3) Konversi ransum yaitu R0 (3,46); R1 (3,35); R2 (3,08) dan R3 (3.03) lebih tinggi dari pada ransum kontrol. Penggunaan limbah sayuran sampai $15 \%$ dalam ransum itik petelur nyata meningkatkan produksi telur, konsumsi dan konversi ransum yang lebih efisien.
\end{abstract}

Kata kunci: Itik petelur, limbah sayuran, produksi telur, konsumsi ransum, konversi ransum

\section{The Effect of Using Waste Vegetable In Ration On Duck To Performance Production}

\begin{abstract}
The waste vegetables ration the effect to the performance production have been done in cage experiment of Poultry Production Farm in Agriculture Studi Programs Khairun University, Ternate, Maluku Utara. An exsperiment using laying ducks padjadjaran age 46 weeks as 64 ducks. The research used to Completely Randomized Design (CRD) with 4 treatments and 4 replications of, $R 0$ (100\% control rations); $R 1$ ( $5 \%$ waste vegetables $+95 \%$ control rations); $R 2$ (10\% waste vegetables $+90 \%$ control rations); and $R 3(15 \%$ waste vegetables $+85 \%$ control rations); and to see the effect of trend pattern of each treatment was done by orthogonal polynomial test. The results (1). Egg production average is $R 0$ (63,04\%); $R 1$ (65,37\%); $R 2(69,79 \%)$ and $R 3(70,57 \%)$ was significantly different $(P<0.05)$; (2). Rations of consumption is R0 (154.36 gram); R1 (153.66 gram); R2 (151.48); and $R 3$ (150.60 gram) was significantly different $(P<0.05)$ between treatment of $R 0, R 2$ and $R 3$; (3) Feed conversion rations is $R 0$ (3.46); $R 1$ (3.35); $R 2$ (3.08) and $R 3$ (3.03) was significantly different $R 0, R 2$ and $R 3$, but not significantly different between treatment of $R 2$ and $R 3$. The use of waste vegetables ration up to $15 \%$ in laying ducks rations real increased egg production, improve consumption and feed conversion rations.
\end{abstract}

Keywords: Layer ducks, waste vegetables, egg production, feed consumption, feed conversion rations

\section{Pendahuluan}

Itik adalah unggas air yang dapat dikelola untuk menghasilkan bahan pangan sumber protein hewani. Eksistensinya selama ini, selain penyumbang produksi telur juga mulai marak di masyarakat perkotaan akan sumbangsihnya berupa produksi daging. Itik merupakan komoditas ternak unggas 
lokal yang sangat potensial sebagai penghasil telur. Produktivitasnya sangat tinggi yaitu 280 butir/ekor/ tahun. Namun ketersediaan bahan pakan khususnya di Maluku Utara sangat terbatas dan menjadi masalah utama bagi peternak. Oleh karena itu diperlukan upaya mencari alternatif bahan pakan yang mudah didapat, tidak bersaing dengan kebutuhan manusia, kualitasnya baik dan tersedia di wilayah tersebut. Salah satunya yang sudah tidak dimanfaatkan bahkan menjadi masalah bagi masyarakat adalah limbah sayuran yang banyak dijumpai di pasar-pasar tradisional.

Kandungan nilai gizi limbah sayuran sangat rendah yang ditunjukan dengan kandungan serat kasar tinggi, diikuti dengan kandungan kadar air yang tinggi serta kandungan protein cukup tinggi berkisar antara 15-24 persen. Limbah sayuran sangat berpotensi untuk dijadikan bahan pakan alternatif untuk itik petelur. Secara fisik, limbah sayuran mudah busuk karena mengandung kadar air yang tinggi, namun secara kimiawi mengandung protein, vitamin dan mineral relatif tinggi dan dibutuhkan oleh ternak unggas khususnya itik. Tekstur limbah sayuran dengan dinding selnya banyak mengandung serat dengan ikatan lignoselulosa dapat mempengaruhi pemanfaatan protein dan mineral tersebut. Oleh karena itu perlu dilakukan pengolahan secara fisik atau dengan mekanisme untuk merenggangkan ikatan ligno-selulosa. Pengukusan dalam pengolahan pangan dikenal dengan steaming, yaitu proses pengolahan panas yang sederhana dengan menggunakan uap panas. Pemasakan dengan panas lembab menyebabkan terjadinya perpindahan panas secara konveksi dari uap panas ke limbah sayuran atau bahan makanan yang dikukus.

Performa produktivitas ternak sangat dipengaruhi oleh ketersediaan ransum baik secara kualitas maupun kuantitas. Beberapa jenis limbah sayuran pasar dapat digunakan sebagai pakan ternak khususnya ternak itik diantaranya kol, caisim, kangkung, dan sawi putih. Limbah kol yang didapat dipasar merupakan bagian kol hasil penyiangan, sedangkan jenis limbah sawi yang banyak dipasaran yaitu sawi hijau dan sawi putih. Jenis limbah sayuran mempunyai kadar air yang cukup tinggi yaitu berkisar antara 90$95 \%$, sehingga jika tidak dimanfaatkan dapat menyebabkan bau busuk karena mudah mengalami kerusakan. Bertitik tolak dari latar belakang tersebut maka dilakukan penelitian dengan judul Pengaruh Penggunaan Limbah Sayuran dalam Ransum Terhadap Performa Produksi Itik Petelur, dimana penggunaan limbah sayuran dalam ransum terlebih dahulu dilakukan pengolahan secara fisik dengan metode pengukusan (steaming).

\section{Bahan dan Metode Bahan Penelitian}

Penelitian dilakukan secara eksperimental di kandang produksi ternak unggas Prodi Peternakan Universitas Khairun. Bahan yang digunakan dalam penelitian yaitu: Itik petelur sebanyak 64 ekor, umur itik 46 minggu. Itik dibagi secara acak ke dalam 16 unit kandang dan disetiap unit kandang terdiri dari 4 ekor itik. Masing-masing unit kandang dilengkapi dengan tempat pakan dan air minum. Ransum yang digunakan yaitu ransum itik petelur dengan kandungan energi metabolis $2800 \mathrm{kkal} / \mathrm{kg}$ dan protein $17 \%$ (Balitnak, 2006). Bahan pakan yang digunakan yaitu ransum komersil.

\section{Metode Penelitian}

Limbah sayuran yang digunakan dalam penelitian ini berasal dari sisa sayuran di pasar-pasar tradisional yang sudah tidak digunakan lagi. Limbah sayuran tersebut terdiri dari campuran kangkung, kol dan sawi putih. Komposisi limbah sayuran yang digunakan relatif sama antara kangkung, kol dan sawi putih. Cara pengolahan limbah sayuran yaitu: limbah sayuran tersebut dibersihkan, kemudian dicacah dan dikukus selama 10 menit. Limbah sayuran yang telah dikukus kemudian dicampurkan dengan ransum dan diberikan pada itik.

Penelitian dilakukan secara eksperimental menggunakan Rancangan Acak Lengkap (RAL) yang terdiri atas 4 perlakuan, yaitu R0 (100\% Ransum kontrol); R1 (5\% limbah sayuran $+95 \%$ ransum kontrol); R2 (10\% limbah sayuran $+90 \%$ ransum kontrol); R3 (15\% limbah sayuran $+85 \%$ ransum kontrol) dan setiap perlakuan diulang sebanyak 4 kali, sehingga didapat 16 unit perlakuan. Guna melihat pola kecenderungan dari masingmasing perlakuan dilakukan uji Polinomial Ortogonal (Gaspersz, 1995). 


\section{Variabel Pengamatan dan Analisis Data}

Variabel yang diamati adalah performa produksi meliputi: produksi telur, konsumsi dan konversi ransum.

\section{Hasil dan Pembahasan}

\section{Pengaruh Pemberian Limbah Sayuran Terhadap Konsumsi Ransum Itik}

Unggas mengkonsumsi ransum terutama dalam memenuhi kebutuhan energi untuk kehidupan sehari-hari. Konsumsi ransum unggas meningkat apabila kandungan energi rendah dan sebaliknya kandungan energi tinggi maka konsumsi ransum menurun. Konsumsi ransum merupakan salah satu faktor yang mempengaruhi produktivitas ternak, dimana ternak hanya bisa hidup, berkembang dan berproduksi apabila mendapat asupan nutrisi yang seimbang sesuai dengan kebutuhan ternak. Rataan konsumsi ransum itik lokal selama 8 minggu dicantumkan pada Tabel 1.

Berdasarkan Tabel 1. rataan konsumsi ransum itik petelur lokal selama 8 minggu penelitian adalah R0 (154,36 gr/ekor/hari); R1 (153,66 gr/ekor/hari); R2 (151,48 gr/ekor/hari) dan R3 (150,66 gr/ekor/hari). Rataan konsumsi ransum tertinggi ditunjukkan perlakuan R0 yaitu tanpa penambahan limbah sayuran. Hasil uji sidik ragam menunjukkan perbedaan nyata $(\mathrm{P}<0,05)$ antara perlakuan $\mathrm{R} 0$; $\mathrm{R} 2$; dan R3, namun tidak berbeda nyata antara perlakuan R0 dan R1 ( $>>0,05)$. Uji polinomial ortogonal (Ilustrasi 2) menunjukkan semakin meningkat penggunaan limbah sayuran sampai $15 \%$ konsumsi ransum itik semakin efisien dan efektif yang ditunjukkan dengan persamaan linier sebesar $\mathrm{Y}=154,81-0,280 \mathrm{X}$ dengan koefisen determinasi $\left(\mathrm{R}^{2}\right)=70,05 \%$ dengan $\mathrm{X}$ adalah persentase penggunaan limbah sayuran dalam ransum dan $\mathrm{Y}$ adalah konsumsi ransum. Artinya persamaan yang digunakan dapat menjadi persamaan penduga terbaik guna mengetahui pengaruh penggunaan limbah sayuran terhadap konsumsi ransum. Adapun grafik persamaan linier disajikan pada Ilustrasi 1 .

Tabel 1. Rataan Konsumsi Ransum Itik Selama 8 Minggu Penelitian

\begin{tabular}{ccccc}
\hline & \multicolumn{5}{c}{ Perlakuan } \\
\cline { 2 - 5 } Ulangan & R0 & R1 & R2 & R3 \\
\hline & & $\ldots \ldots \ldots \ldots \ldots$ & $(\mathrm{gr})$ & $\ldots \ldots \ldots \ldots \ldots \ldots$ \\
& & & & \\
\hline 1 & 155,00 & 153,25 & 152,25 & 150,00 \\
3 & 154,25 & 154,00 & 151,40 & 151,25 \\
4 & 152,80 & 153,40 & 151,50 & 151,40 \\
Total & 155,40 & 154,00 & 150,75 & 150,00 \\
Rata-rata & 617,45 & 614,65 & 605,9 & 602,65 \\
\hline
\end{tabular}

Keterangan:

$\mathrm{R} 0=100 \%$ Ransum kontrol

$\mathrm{R} 2=90$ Ransum kontrol $+90 \%$ limbah

$\mathrm{R} 1=95$ Ransum kontrol $+90 \%$ limbah sayur sayur

$\mathrm{R} 3=85$ Ransum kontrol $+15 \%$ limbah sayur

Huruf yang berbeda pada baris yang sama menunjukkan perbedaan nyata $(\mathrm{P}<0,05)$

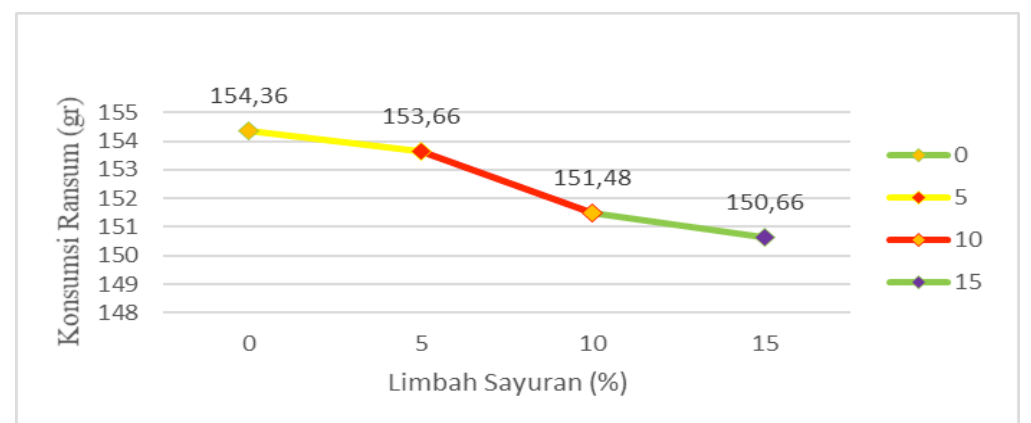

Ilustrasi 1. Grafik Persamaan Linier Konsumsi Ransum Itik Petelur 
Rataan konsumsi ransum hasil penelitian lebih efisien pada penambahan limbah sayuran dalam ransum, dibandingkan rataan konsumsi ransum penelitian sebelumnya pada itik petelur, yaitu 154 gram/ekor/hari (Ketaran dan Prasetyo, 2002). Namun pada perlakuan ransum kontrol konsumsi ransum relatif sama dengan penelitian sebelumnya yaitu 154,36 gr. Wahyu (2004) menyatakan bahwa energi dalam ransum merupakan faktor penentu banyaknya konsumsi pakan karena ternak mengkonsumsi pakan untuk memenuhi kebutuhan energinya. Pengolahan limbah sayuran sebelum diberikan pada itik dilakukan guna mencegah pembusukan, meningkatkan palatabilitas dan kecernaan yang pada gilirannya dapat meningkatkan produktivitas ternak. Teknik pengolahan bahan pakan termasuk pengolahan limbah sayuran secara fisik dengan metode pengukusan menghasilkan nilai kecernaan yang lebih tinggi sehingga berdampak pada semakin efisien dalam penggunaan ransum dan peningkatan produktivitas (Emy Saelan et al. 2016). Efisiensi penggunaan ransum dipengaruhi oleh beberapa faktor diantaranya kemampuan ternak dalam mencerna bahan pakan, kecukupan zat pakan untuk hidup pokok, pertumbuhan dan fungsi tubuh serta jenis ransum yang digunakan (Campbell et al., 2006).

\section{Pengaruh Penggunaan Limbah Sayuran dalam Ransum terhadap Produksi Telur Itik}

Kemampuan produksi telur itik dipengaruhi oleh faktor genetik dan lingkungan, yang salah satu faktor berupa lingkungan sangat berpengaruh terhadap produktivitas itik yaitu ransum. Rataan produksi telur itik Duck Day Production $(D D P)$ selama 8 minggu dicantumkan pada Tabel 2.

Berdasarkan Tabel 2. rataan persentase produksi telur itik Duck Day Production $(D D P)$ selama 8 minggu penelitian adalah R0 (63,04\%); R1 (65,37\%); R2 (69,79\%); dan R3 $(70,57 \%)$. Hasil uji sidik ragam menunjukkan perbedaan yang nyata $(\mathrm{P}<0,05)$ antara perlakuan R0; R1; dan R2, namun tidak berbeda nyata antara perlakuan R2 dan R3 $(\mathrm{P}>0,05)$. Rataan produksi telur tertinggi ditunjukkan perlakuan R3 yaitu sebesar $70,57 \%$. Guna melihat pola kecenderungan peningkatan persentase produksi telur dilanjutkan dengan uji polinomial ortogonal.

Tabel 2. Persentase Rataan Produksi Telur Itik selama 8 Minggu Penelitian

\begin{tabular}{|c|c|c|c|c|}
\hline \multirow[b]{2}{*}{ Ulangan } & \multicolumn{3}{|c|}{ Perlakuan } & \multirow[b]{2}{*}{ R3 } \\
\hline & $\mathrm{RO}$ & R1 & R2 & \\
\hline \multicolumn{5}{|c|}{$(\%)$} \\
\hline 1 & 64,25 & 63,54 & 67,71 & 71,88 \\
\hline 2 & 61,83 & 63,54 & 70,83 & 69,79 \\
\hline 3 & 62,88 & 66,67 & 69,79 & 69,79 \\
\hline 4 & 63,21 & 67,71 & 70,83 & 70,83 \\
\hline Total & 252,17 & 261,46 & 279,16 & 282,29 \\
\hline Rata-rata & 63,04 & 65,37 & 69,79 & 70,57 \\
\hline
\end{tabular}

Keterangan:

$$
\begin{aligned}
& \text { R0 }=100 \% \text { Ransum kontrol } \quad \text { R1 }=95 \text { Ransum kontrol }+90 \% \text { limbah sayur } \\
& \mathrm{R} 2=90 \text { Ransum kontrol }+90 \% \text { limbah } \quad \mathrm{R} 3=85 \text { Ransum kontrol }+15 \% \text { limbah sayur }
\end{aligned}
$$

Huruf yang berbeda pada baris yang sama menunjukkan perbedaan nyata $(\mathrm{P}<0,05)$

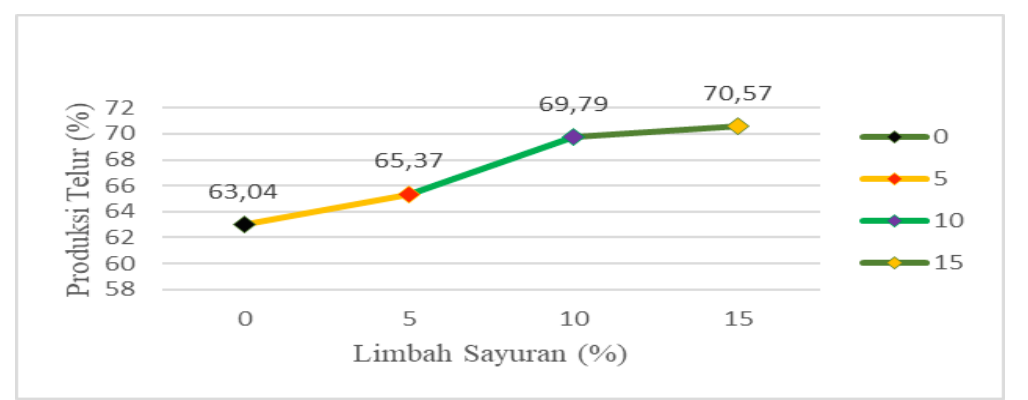

Ilustrasi 2. Grafik Persamaan Linier Persentase Produksi Telur Itik 
Uji polinomial orthogonal (Ilusrtasi 2) terjadi peningkatan produksi telur seiring dengan semakin meningkatnya penggunaan limbah sayuran dalam ransum sampai $15 \%$ pada persamaan linier sebesar $\mathrm{Y}=63,140+0,540 \mathrm{X}$ dengan koefisien determinasi $\left(\mathrm{R}^{2}\right)$ sebesar $80,05 \%$ dengan $X$ adalah persentase penggunaan limbah sayuran dalam ransum dan $\mathrm{Y}$ adalah persentase produksi telur yang dihasilkan. Artinya persamaan yang digunakan dapat menjadi suatu persamaan penduga terbaik guna mengetahui bahwa $80,05 \%$ peningkatan produksi telur dipengaruhi oleh penggunaan limbah sayuran dalam ransum. Produksi telur dipengaruhi oleh beberapa faktor yaitu genetik, bangsa, umur dewasa kelamin, obat-obatan, zat nurisi, tingkat protein dalam ransum, cara pemeliharaan dan suhu lingkungan (Anggorodi, 1985).

Berdasarkan Tabel 2 dapat diketahui bahwa semakin besar persentase penggunaan limbah sayuran dalam ransum sampai $15 \%$ menghasilkan peningkatan produksi telur. Hal tersebut, karena limbah sayuran memiliki kandungan protein tinggi yang dapat menunjang kecukupan asupan nutrien untuk mencapai produktivitas yang maksimal. Hasil analisa proksimat menunjukkan limbah sayuran di pasar tradisional memiliki kandungan protein 20,76-29,18\% serta kandungan mineral yang tinggi diantaranya kalsium (Ca) (Muktiani et al., 2013). Pengolahan limbah sayuran dengan pengukusan (steam) sebelum diberikan pada itik dapat memperbaiki nilai guna dari limbah sayuran tersebut. Hal ini dapat dilihat dari perbaikan dan peningkatan kecernaan kecernaan akibat teknik proccesing, membuat ketersediaan nutrien meningkat dan jumlah nutrien yang diserap dapat memenuhi kebutuhan ternak dalam mencapai produksi maksimal. Hal ini dapat dilihat dari tingginya nilai kecernaan protein limbah sayuran hari pengukusan sebesar 70,22\% dengan kandungan protein yaitu 20,52\% (Abun et al., 2007).

\section{Pengaruh Pemberian Limbah Sayuran Terhadap Konversi Ransum Itik Lokal}

Konversi ransum merupakan suatu ukuran yang dapat digunakan untuk menilai efisiensi penggunaan ransum dan kualitas ransum (Fan et al., 2008). Rataan konsumsi ransum itik lokal selama 6 minggu dicantumkan pada Tabel 3 .

Berdasarkan Tabel 3. rataan konversi ransum itik petelur lokal selama 8 minggu penelitian adalah R0 (3,46); R1 (3,35); R2 $(3,08)$ dan R3 (3.03). Rataan konversi ransum tertinggi pada perlakuan R1 (kontrol) tanpa penambahan limbah sayuran yaitu 3,46. Hasil uji sidik ragam menunjukkan perbedaan nyata $(\mathrm{P}<0,05)$ antara perlakuan $\mathrm{R} 0$; R2; dan R3, namun tidak berbeda nyata antara perlakuan $\mathrm{R} 0$ dan $\mathrm{R} 1$ serta $\mathrm{R} 2$ dan R3 (P>0,05). Guna mengetahui perbedaan respon antar perlakuan terhadap konversi ransum itik petelur melalui uji polinonial ortogonal.

Tabel 3. Rataan Konversi Ransum Itik Lokal Selama 8 Minggu Penelitian

\begin{tabular}{ccccc}
\hline & \multicolumn{5}{c}{ Perlakuan } & R3 \\
\cline { 2 - 5 } Ulangan & $\mathrm{R} 0$ & $\mathrm{R} 1$ & $\mathrm{R} 2$ & 3,15 \\
2 & 3,50 & 3,35 & 3,20 & 3,00 \\
2 & 3,40 & 3,40 & 3,00 & 2,95 \\
3 & 3,50 & 3,35 & 3,00 & 3,00 \\
4 & 3,45 & 3,30 & 3,10 & 12,10 \\
Total & 13,85 & 13,40 & 12,30 & 3,03 \\
\hline Rata-rata & 3,46 & 3,35 & 3,08 &
\end{tabular}

Keterangan:

$$
\begin{aligned}
& \mathrm{R} 0=100 \% \text { Ransum kontrol } \quad \mathrm{R} 1=95 \text { Ransum kontrol }+90 \% \text { limbah sayur } \\
& \mathrm{R} 2=90 \text { Ransum kontrol }+90 \% \text { limbah } \quad \mathrm{R} 3=85 \text { Ransum kontrol }+15 \% \text { limbah sayur } \\
& \text { sayur }
\end{aligned}
$$

Huruf yang berbeda pada baris yang sama menunjukkan perbedaan nyata $(\mathrm{P}<0,05)$ 


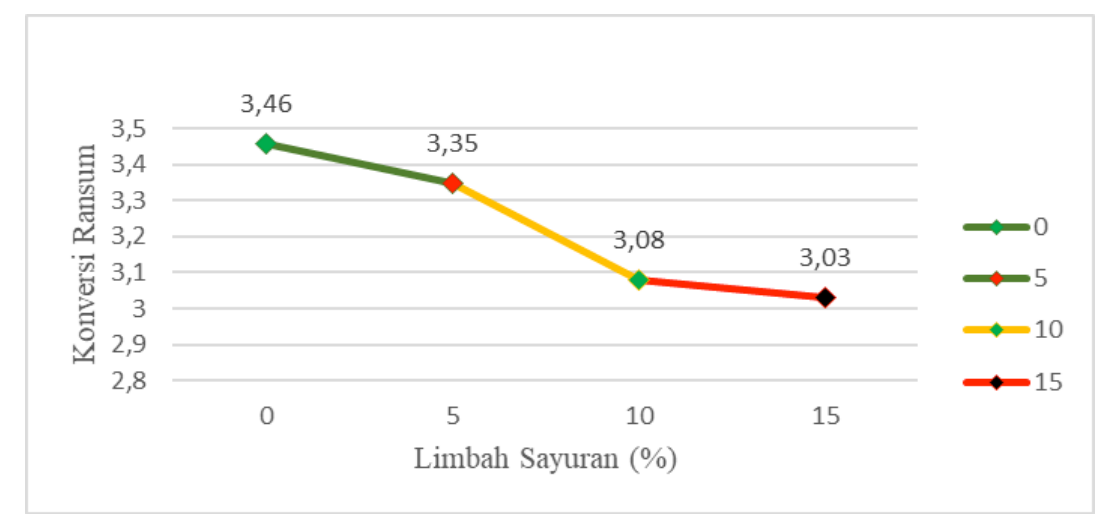

Ilustrasi 3. Grafik Persamaan Linier Konversi Ransum Itik Petelur

Uji polinomial ortogonal (Ilustrasi 3) menunjukkan semakin meningkat penggunaan limbah sayuran sampai $15 \%$ konversi ransum itik semakin efisien dan efektif yang ditunjukkan dengan persamaan linier sebesar $\mathrm{Y}=3,463+0,20 \mathrm{x}-0,011 \mathrm{x}^{2}+0,001 \mathrm{x}^{3}$, dengan koefisen determinasi $\left(\mathrm{R}^{2}\right)=89,70 \%$. Nilai Koefisien determinasi $\left(\mathrm{R}^{2}\right)$ menunjukkan tingkat pengaruh perlakuan terhadap konversi ransum itik petelur sebesar $89,70 \%$. Grafik persamaan linier Ilustrasi 3 dapat dijelaskan bahwa konversi ransum itik petelur pada penggunaan limbah sayuran $15 \%$ semakin baik, hal ini didukung juga dengan semakin efisiennya penggunaan ransum dalam menunjang presentase peningkatan produksi telur.

Prasetyo et al. (2004) rataan nilai konversi ransum itik hasil persilangan Mojosari dengan Alabio sebesar 4,10. Nilai konversi ransum hasil penelitian ini lebih efisien dari hasil penelitian sebelumnya, dimana rataan nilai konversi ransum pada penelitian ini yaitu 3,03 pada penambahan limbah sayuran $15 \%$ dalam ransum. Hal tersebut menunjukkan semakin rendah nilai konversi ransum, maka ransum tersebut semakin efisien dalam penggunaannya, sebaliknya semakin tinggi nilai konversi ransum semakin rendah efisiensi penggunaan ransum (Nurhayati, 2013).

\section{Kesimpulan}

Berdasarkan hasil penelitian dan pembahasan maka dapat disimpulkan bahwa penggunaan limbah sayuran dalam ransum itik petelur sampai $15 \%$ dapat meningkatkan produksi telur, konsumsi dan konversi ransum lebih efisien dan efektif.

\section{Ucapan Terima Kasih}

Pada kesempatan ini penulis mengucapkan terima kasih yang sebesar- besarnya kepada : Dana "DIPA Universitas Khairun Ternate" Tahun Anggaran 2018. LPPM Universitas Khairun yang telah memberi peluang dalam mendapatkan dana penelitian dan semua pihak yang telah membantu dalam pelaksanaan penelitian.

\section{Daftar Pustaka}

Abun, Saefulhadjar D, 2007. Efek Pengolahan Limbah Sayuran Secara Mekanis Terhadap Nilai Kecernaan pada Ayam Kampung Super. JJ-101. J. Ilmu Ternak 7. 81-86.

[Balitnak] Balai Penelitian Ternak. 2006. Pendatang baru penghasil telur: Itik $M A$. Bogor: Unit Komersialisasi Teknologi Balitnak. www.balitnak.litbang.deptan.go.id (15 Mei 2018).

Campbell JR, Kenealy MD, Campbell, KI., 2006. Animal Sciences 4th Ed. New York (US) McGrawHill.

Fan, H.P., Xie M., Wang, W.W, Hou S.S \& Huang, W.2008. Effect of dietary energy on growth performance and carcass quality of white growing pekin ducks from two to six weeks of age. Poult Sci. 86:2441-2449.

Gaspersz, V. 1995. Teknis Analisis Dalam Penelitian Percobaan Jilid I. Penerbit Tarsito Bandung. Hal. 62-111.

Gaspersz, V. 1995. Teknis Analisis Dalam Penelitian Percobaan Jilid II. Penerbit Tarsito Bandung. Hal. 107-126.

Ketaren, P.P dan H. Prasetyo. 2002. Pengaruh pemberian pakan terbatas terhadap produktivitas itik silang mojosari $x$ alabio (MA): 1. Masa 
bertelur fase pertama umur 20-43 minggu. JITV Vol. 7 (1): 38-45.

Muktiani AJ, Achmadi BIM, Tampoebolon, Setyorini R. 2013. Pemberian Silase Limbah Sayuran yang disuplementasi dengan Mineral dan Alginat sebagai Pakan Domba. J, Pengembangan Peternakan Tropis 2. 144-150.

Nurhayati. 2013. Penampilan Ayam Pedaging yang Mengkonsumsi Pakan Mengandung Kulit Nanas Disuplementasi dengan Yoghurt. Agripet 13 (02) : 15-20.

Prasetyo, L. H, T. Susanti, P. P. Kataren, E. Juwarini dan M. Purba. 2004. Pembentukan itik lokal petelur MA G3 dan pedaging seleksi dalam galur pada bibit induk alabio dan itik mojosari generasi F3. Kumpulan Hasil-hasil Penelitian Tahun Anggaran 2004. Balai PenelitianTernak Ciawi, Bogor. Hal. 7082.

Emy Saelan, Tuti Widjastuti, Iwan Setiawan, Hendi Setiyatwan, 2016. Steaming Technology Ration Product Inmplementation at Padjadjaran local Duck on the Metabolizable Energy, Digestible Organic Matter and Protein Ration Value. Scientific Papers Series Management, Economic Engineering in Agriculture and Rural Development Vol. 16, Issue 3 . 